\title{
COSMETICS BRAND EQUITY FORMATION IN AWARENESS OF LATVIAN CONSUMER
}

\author{
Jelena Šalkovska ${ }^{1}$, Anda Batraga ${ }^{2}$, Aelita MežPaPA ${ }^{3}$ \\ University of Latvia (Latvia)
}

\begin{abstract}
Creation of strong brand and increment of brand's equity in the market is main goal of business. Usage of brand equity concept allows brand owners to sell branded products at higher price, gain greater market share, better promote products in the market, penetrate in market more easily, acquire more loyal consumers, improve effectiveness of marketing communications and enlarge product lines more successfully. Therefore for last 20 years brand's equity conception, that consists from financial and consumer perceived brand's equity, has become increasingly actual. It is also important task for brands in Latvian cosmetics market, because market itself is strongly saturated, highly competitive, and brand communication is very active, and therefore this kind of market requires brands to create their own unique approach, so they could stand out and successfully compete with other brands.

KEYWORDS: consumer based brand equity, cosmetic brand, perceived quality.
\end{abstract}

JEL CODE: M31

\section{Introduction}

If the brand equity is being perceived as the whole set of consumers perceptions about brand, it is correct to state that it has strong link with consumer's knowledge about the brand. Consumers brand knowledge or awareness affects its perception and beliefs of the brand and creates certain attitude. It is important that consumer remembers the brand, believes it to be valuable and maintains positive associations in his memory for long period of time. Therefore in this situation brands must utter consumers in different levels of consumer's equity - not only in rational / functional, but also within emotional and social level of values. It makes brand's memorization more easier for consumer and moves him towards the decision of purchase. Consumer's knowledge about brand is being delivered through the process of brands communication with the consumer. Marketing communication is the most important tool for consumers brand's knowledge, per-

1 Ję̦ena Šalkovska - m.oec., lecturer of Faculty of Economics and Management at University of Latvia, Marketing Department. Scientific interests: Integrated Marketing Communication, Internet Marketing, Branding

E-mail: jelena.salkovska@lu.lv

Tel. +371 29615933

2 Anda Batraga - dr.oec. associate professor, head of Chair of Marketing University of Latvia. Scientific interests: marketing and marketing communication. Integrated Marketing Communications. Brand development. Corporate Identity

E-mail: anda.batraga@1u.lv

Tel.: + 37129224223

3 Aelita Mežpapa - m. oec., graduate student, University of Latvia, Faculty of Economics and Management, Marketing Management. Scientific interests: Brand development, Integrated Marketing Communication, Consumer Behavior

E-mail: aelita.mezpapa@gmail.com

Tel. +371 29133346 
ception and, therefore, most important tool for process of consumer value creation. Brand managers have to know how to successfully deliver desired brand image, position and value to their consumers through the marketing communication. For brand managers this is one of the most challenging tasks. Interaction between sources of brand equity and consumers' positions is important, so the consumer could understand uniqueness of brand and other differentiation attributes in comparison with other brands. It is also important to ensure that consumer understands values created by brand.

Problem. The authors explore cosmetics brand equity formation in awareness of Latvian consumer. This topic in the Latvian cosmetics market haven't been researched, and the clear criteria with are the basis on consumer's choice of brands haven't been identified as well. Marketing specialists more depend on their own and their colleague's subjective knowledge or on some researches that has been performed in some other countries. That has led to development of large amount templated advertisements and standardized communication. In Latvia these facts are partly explained with relatively small cosmetics market, however authors believe that also in small markets brands should be more successful, and therefore attention to brands equity communication and formation in consumer consciousness has to be taken into account. Authors see huge potential for brand equity creation conception in consumer perception, especially in small, saturated and highly competitive markets.

Purpose. The aim of this paper is based on theoretical findings about consumer based brand equity creation, and authors' performed qualitative and quantitative researches, to examine cosmetic brands equity and its formation in Latvian consumers' awareness.

Object. In this paper object of the research is cosmetic brands in Latvia and process of its consumer based brand equity creation and management.

Tasks:

- explore brand performance in the market, determine main values and marketing communication with the consumers;

- examine brand consumer attitude towards the cosmetic brands, their equity creation and main criteria in Latvian cosmetic field;

- analyze gained data, evaluate gained insights, and provide analytical summary about cosmetic brands in Latvia.

Methods. Authors used following research methods: refractive analysis of scientific literature, interviews with Latvian marketing specialists, interviews with Latvian cosmetic market experts, Latvian consumer quantitative survey. The empirical study analyzed in this article consists of three related parts. Each of them explained or preparing the ground for the next part of the study.

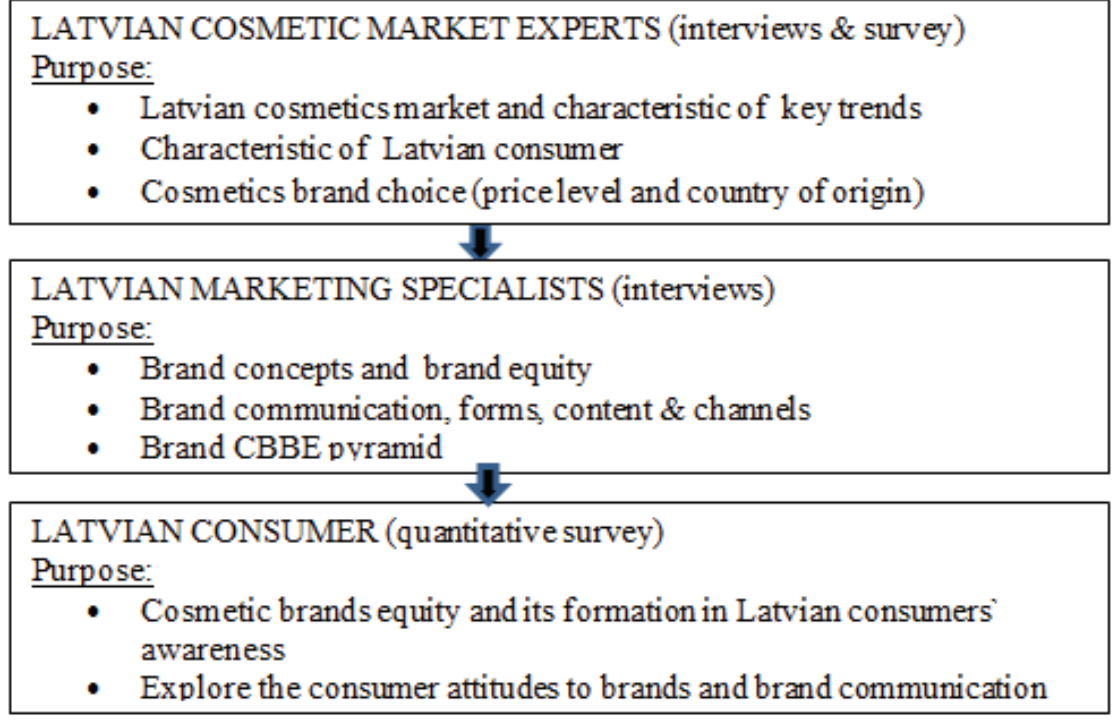

Figure 1. The research process and participants

Source: created by authors 
Part 1 of the study analyzes the Latvian cosmetic market and selects the researched cosmetic brands. The authors nominated two dimensions by which to choose the brand: price category (low, medium and high price) and country of origin (European, Latvian and Russian / Eastern brand). The price category is identified as a leading category and the further brand analysis is done directly by this category. Brands in each category were ranked accordingly to experts survey findings.

In Part 2 based on the marketing and brand managers interviews and on-line material assistance authors analyze consumer value of seven selected cosmetic brands. The authors establish and analyze consumer based brand equity pyramid for each of the investigated brands and examines ways of marketing communication how this value is transferred to their customers. Such research is necessary to be able to compare the obtained results with the consumer's view and attitude of empirical studies in Part 3.

The Part1 and Part 2 formed the basis for the quantitative research. General group in this consumer research conform all Latvian citizens between 15-65+ years that buys and intentionally uses retail cosmetics for face and body (not covered decorative cosmetics and perfumery). After performed calculations, and assuming that significance level is 0.95 or $05 \%$, the minimal sample size is 385 respondents. Sample size has been made after proportional selection principle. In order to define sample size, authors used the quota method, and took into account number of citizens, proportionally dividing total number of respondents into relatively appropriate general set by age groups. For data analysis descriptive comparisons of statistical data were applied.

\section{Theoretical findings on consumer based brand equity creation.}

Brand equity is one of main marketing concepts. Different opinions exist what the brand equity really is, still there is no one common definition. Literature is pretty much fragmentized. Brand equity as concept first appeared in late 80's. Various brand equity definitions have been suggested. Most of them are based on belief that brands are located in consumer's conciseness. Others approach brand equity from finance perspective, and considers the brand equity as company's financial asset. Authors strongly believe that K. L. Keller and D. Aaker have provided the most precise explanation of brand equity concept, and therefore the remaining paper is based on Keller's and Aaker's provided models and approaches.

If company wants to make profits, its brand needs consumer's value. Most of the marketing academic researches points out and are based on belief that brand strength from consumer's point of view is found in consumers' minds. Brand equity from consumer's point of view pertains to value that consumers perceive or attribute to brand. Brand equity is hidden in existing and potential consumers` minds and experiences, that they have been directly or indirectly acquired regarding to brand over certain period of time (Kotler, Keller, 2006: 276). Kotler and Keller defines brand equity as bridge that is built between marketing investments and companies products in order to create brands and consumers knowledge about them (Kotler, Keller, 2006: 276).

Academic literature distinguishes two main types of brand equity - finance approach that is based on financial performance and points out that brand equity is delivered to consumer through logo, name, slogan and symbols. It values brand equity in terms of money (price, market share, profitability etc.) and therefore adds financial value to companies. Here main focus is on the results, actual or conditional business deals that are done with an intention to improve brand equity to relevant stakeholders (Shimp, 2010).

Other approach is based on brands consumer value. In order for company to make a profit, brand needs consumer value. Many marketing academic researches focus on and are based on assumption that brand strength from consumer's perspective hides in consumers minds. Consumer brand equity then pertains to value that consumers perceives or attributes to brand. Brand strength hides in existing and potential clients' minds and experiences that they have acquired regarding to brand over certain period of time. Kotler and Keller (Kotler, Keller, 2006) defines that brand equity is the bridge between marketing investments and companies products which exists in order to create brands and clients knowledge about brands. Just like with brand equity conception, there is no one common approach also about conception of consumer based 
brand value. Aaker in 1991 and Keller in 1993 developed basics for consumer brand value researches. From psychology's cognitive approach Aaker defines consumer based brand equity as a set of brands assets and liabilities, that is related to brand, its name and symbols that adds or subtracts value from branded products or services and/or brand consumers. This value is brand awareness, perceived quality, associations with brand, brand loyalty and other values.

Table 1. Different definitions and beliefs on brand equity concept

\begin{tabular}{|c|c|}
\hline Study & \begin{tabular}{|c|} 
Description of the Concept \\
\end{tabular} \\
\hline $\begin{array}{l}\text { American } \\
\text { Marketing Association }\end{array}$ & $\begin{array}{l}\text { From a consumer perspective, brand equity is based on consumer attitudes about } \\
\text { positive brand attributes and favorable consequences of brand use (American Marketing } \\
\text { Association, 2009) }\end{array}$ \\
\hline $\begin{array}{l}\text { The Marketing } \\
\text { Science Institute }\end{array}$ & $\begin{array}{l}\text { The set of associations and behaviors on the part of the brand's consumers, channel mem- } \\
\text { bers, and parent corporation that permits the brand to earn greater volume or greater mar- } \\
\text { gins than it would without the brand name and that gives the brand a strong, sustainable, and } \\
\text { differentiated advantage over competitors. (Fayrene, Lee, 2011) }\end{array}$ \\
\hline Aaker & $\begin{array}{l}\text { The value consumers associate with a brand, as reflected in the dimensions of brand aware- } \\
\text { ness, brand associations, perceived quality, brand loyalty and other proprietary brand asset } \\
\text { (Batraga, Medne, Dmitrijeva, Šalkovska 2013:3) }\end{array}$ \\
\hline $\begin{array}{l}\text { Kamakuram, Russel, } \\
\text { Lassar u.c. }\end{array}$ & $\begin{array}{l}\text { Consumer-based brand equity occurs when the consumer is familiar with the brand and } \\
\text { holds some favorable, strong, and unique brand associations in the memory (Kamakura, } \\
\text { Russell, 1993: 9) }\end{array}$ \\
\hline Keller & $\begin{array}{l}\text { The differential effect of brand knowledge on consumer response to the marketing of the } \\
\text { brand. Brand knowledge is the full set of brand associations linked to the brand in long-term } \\
\text { consumer memory (Batraga, Medne, Dmitrijeva, Šalkovska 2013: 3) }\end{array}$ \\
\hline Aaker & $\begin{array}{l}\text { Brand equity is: (1) Loyalty (brand's real or potential price premium), (2) loyalty (consum- } \\
\text { er satisfaction based), (3) perceived comparative quality, (4) perceived brand leadership, } \\
\text { (5) perceived brand value (brand's functional benefits), (6) brand personality, (7) consum- } \\
\text { ers perception of organization (trusted, admired or credible), (8) perceived differentiation to } \\
\text { competing brands, (9) brand awareness (recognition \& recall), (10)market position (marke } \\
\text { share), prices and distribution coverage (Batraga, Medne, Dmitrijeva, Šalkovska 2013: 3) }\end{array}$ \\
\hline Pullig & $\begin{array}{l}\text { Brand equity ultimately resides in the mind of the consumer. A brand is essentially a per- } \\
\text { ceptual entity and this is the reason it cannot be accounted for in a financial statement. The } \\
\text { value of the brand is essentially made up of two dimensions: 1) brand awareness and 2) } \\
\text { brand image. These two dimensions represent: 1) How well known is your brand? and 2) } \\
\text { What does your brand represent? (Pullig, 2008: 1) }\end{array}$ \\
\hline Arvidsson & $\begin{array}{l}\text { Brand equity is the main concept of the company's marketing activities evaluation. (Isabel } \\
\text { Buil Eva Martínez Leslie de Chernatony, 2013:62-74) }\end{array}$ \\
\hline Gunelius & $\begin{array}{l}\text { The tangible and intangible value that a brand provides positively or negatively to an orga- } \\
\text { nization, its products, its services, and its bottom-line derived from consumer knowledge, } \\
\text { perceptions, and experiences with the brand.(Gunelius, 2014) }\end{array}$ \\
\hline Tybout and Calder & $\begin{array}{l}\text { Brand equity is the perceived brand meaning in the minds of consumers. Lacking a mean- } \\
\text { ingful perception, a brand has no equity (Tybout, Calder, 2010) }\end{array}$ \\
\hline
\end{tabular}

Successful marketing, when developing products, is based on comprehension about consumer needs and desires. Successful performance of company is consumer oriented approach. It is important for marketers to understand consumer, learn what different brands mean to them, and how knowledge about brands affect consumer's behavior. Authors believe that brand consumer value main lesson is that brand strength is located at consumer's knowledge about brands and knowledge together with experiences forms brand image, associations and value in consumer conciseness. In other words, brand strength is located in human hearts and minds. From brand consumer value conception approach, the key is consumer awareness about brand because knowledge creates this effect of distinctness (Keller, 2013: 67-105). 
Due to growing globalization the impact of different cultures is becoming increasingly important problem. It is being asserted that culture has the longest and resistant impact on consumer behavior and attitude. Consumer behavior and life style creates stronger connection than other social influence factors (McCort, Malhorta, Naresh, 1993: 91-127). Culture factors have great impact on consumer behavior, and in national level there are several consumer differences. (Monday, 2015).

Marketing communication is a tool that companies use to inform, convince and remind consumers about the brands what they are selling. It means that marketing communication is voice of brand and tool with which brand can create dialogue and create relationships with consumers. (Keller, 2013: 217-220). Communication is brands weapon. It can uncover what is invisible, reveal main differences that packing hides, that otherwise often doesn't stand out from competitors offers. It alone can maintain affection to brand; promote intangible values, even if the loyalty is cankered by many discounted products that are around. (Kapferer, 2008: 244). In order to increase brand awareness, brands have to supply consequent information to consumers by using integrated marketing communication with more effective media channels. Marketing communication strategy's development is very complex and challenging process that is significantly affected by company's budget, changing communication environment, channels and changes in consumer behavior. In the context of brand equity creation, communication strategy should be developed by taking into consideration how to coherently and integrated use different communication opportunities for consumer brand equity creation (Keller, 2013: 220).

\section{Consumer based brand equity in Latvian cosmetic market}

Due to new age of digitalization, everything is changing, including consumers, their habits, communication ways, types and channels. Communication is not one-way message anymore. It is dialogue with consumer and the most important and alarming this is that it has become as process that cannot be controlled anymore. Successful growth of brand now is possible only if the deep consumer needs and value comprehension is performed.

While performing Latvian consumer survey, very large consumer interest about cosmetics was observed. Almost $95 \%$ of respondents even answered to all open survey's questions, including questions about desired relationships with cosmetic brands, associations, communication, and also about brand criticism. It proves that for the consumer cosmetic products has become an important ingredient of the live quality.

Only $19 \%$ from all respondents doesn't pay attention to brands and purchases only those products that seems more appropriated when visiting shop. Rest $81 \%$ of respondents buys brands and they are important for them. $8 \%$ of respondents have one favorite brand. $24 \%$ of respondents have $2-3$ favorite brands, but $18 \%$ only occasionally choses different brand. These data approves that brands have significant roles in consumer's lives and they are loyal to brands. It is also approved by fact that $30 \%$ of respondents, that doesn't have favored brands, choses the product with brand that is known to them, because brand is guarantee of consumers expected value, and it highlights differences between various products. These relationships are provided in following table: 


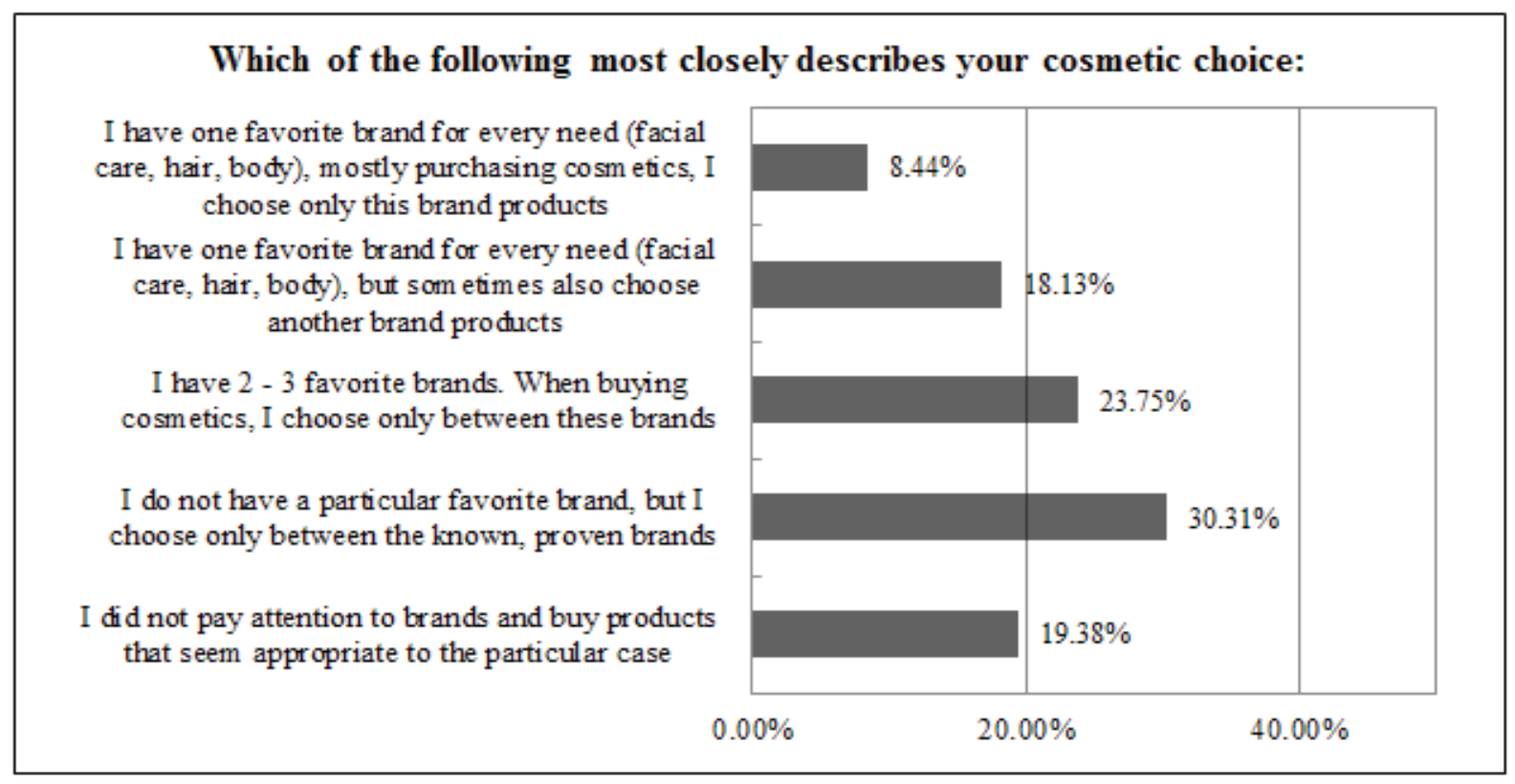

Figure 2. Cosmetic brand choice, $n=385$

Source: Results of author's performed survey

Consumers doesn't care what is brand. The brand managers are interested in it. Consumers are only interested why this brand exist and what it does. Therefore it is essential to understand main criteria, which are on the basis of consumer's choice of brands.

In survey's question in scale 1-10 (10 - the most important; 1 - not important at all) consumers were asked to evaluate different reasons or criteria, that determines their cosmetic brand choice. The results show that the most important criteria for consumers are quality that has been rated with 9.03 points (standard deviation - 1.77). $69 \%$ of respondents gave the highest value to quality (10 points of 10). According to results, the second most important criteria for consumers are price. It was rated with 8.54 points (standard deviation - 1.9). It means that it is important for consumers to buy cosmetic that has some kind of discount or special offer. The least important belief regarding to cosmetics is that this fashion product. Consumers are also very little interested in what cosmetics celebrities use. It means that idol times in cosmetics industry are over. Also brand advertisement's importance was rated quite low, because consumers founds it uninteresting and aggressive. This impression is formed because of standardized, global cosmetic brand and lack of creative ideas implementation in the cosmetics advertisements.

When evaluating various evaluations of criteria in scale 1-10, authors highlight 3 main groups of consumer values: functionality (rational values), emotional and social values. When analyzing consumer evaluated brand attributes (fig. 3) authors conclude that next to functional brand attributes, what consumers evaluated with high 7.91 points (standard deviation -2.42), the similarly strong cosmetic brand evaluation stands out also emotional values that consumers have rated with 7.97 points (standard deviation - 2.33). Authors conclude that positive emotions have essential meaning when consumers are choosing the brands. By unifying the functional and emotional attributes, it is possible to significantly increase cosmetic brand opportunity to be noticed and become as TOP 1 choice. Emotions are very powerful weapon. 


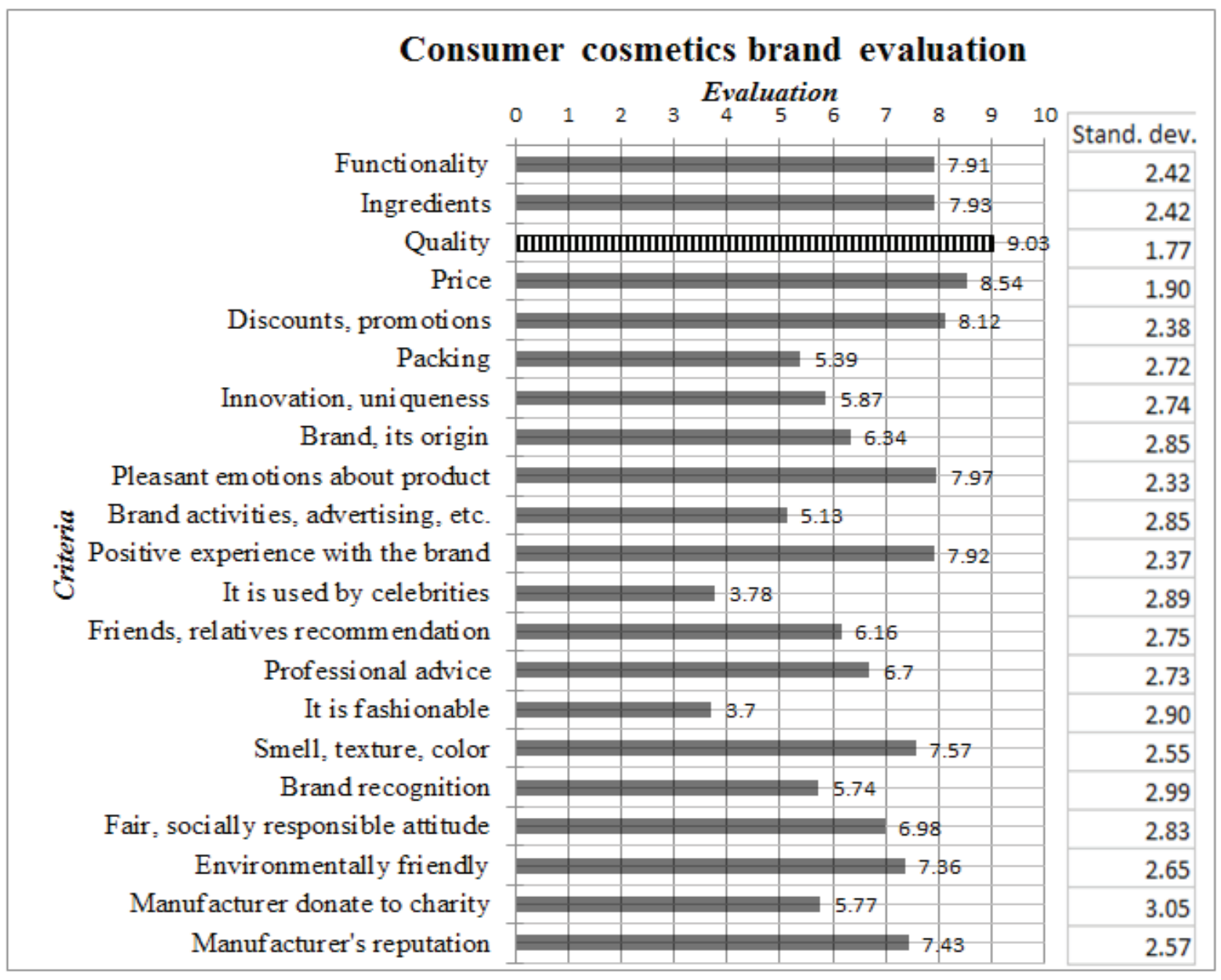

Figure 3. Cosmetics brand evaluation in scale $1-10, n=385$

Source: Results of author's performed survey

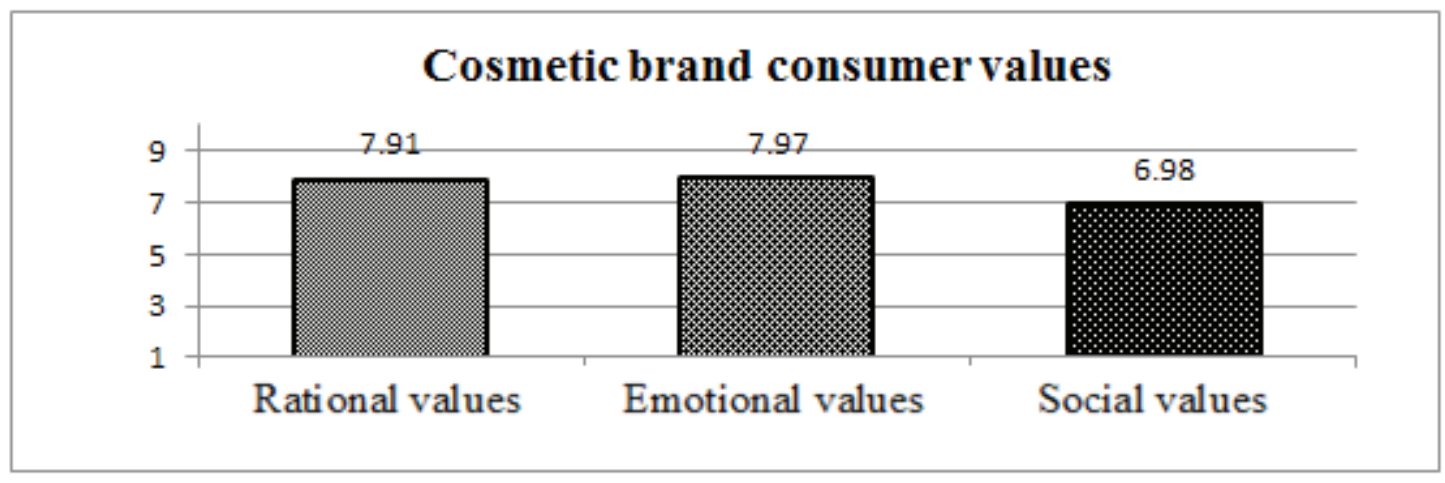

Figure 4. Cosmetic brand consumer values, $n=385$

Source: Results of author's performed survey

Next to rational and emotional values, the social values also announcing themselves in consumer's minds - 6.98 points (fig. 3). It approves that it is important for Latvian consumer that brand are forming better, socially responsible environment around brands, and their performance would not negatively affect environ- 
ment. By assessing the consumer attitude against cosmetic brands authors conclude that cosmetic brands in Latvian market need positioning, that would be based not only on rational and emotional but also on social society's values, because social responsibility are becoming increasing important factor for Latvian consumers.

It is important to understand what are information sources, where and what communication channels they are seeking and finding the information about brands.

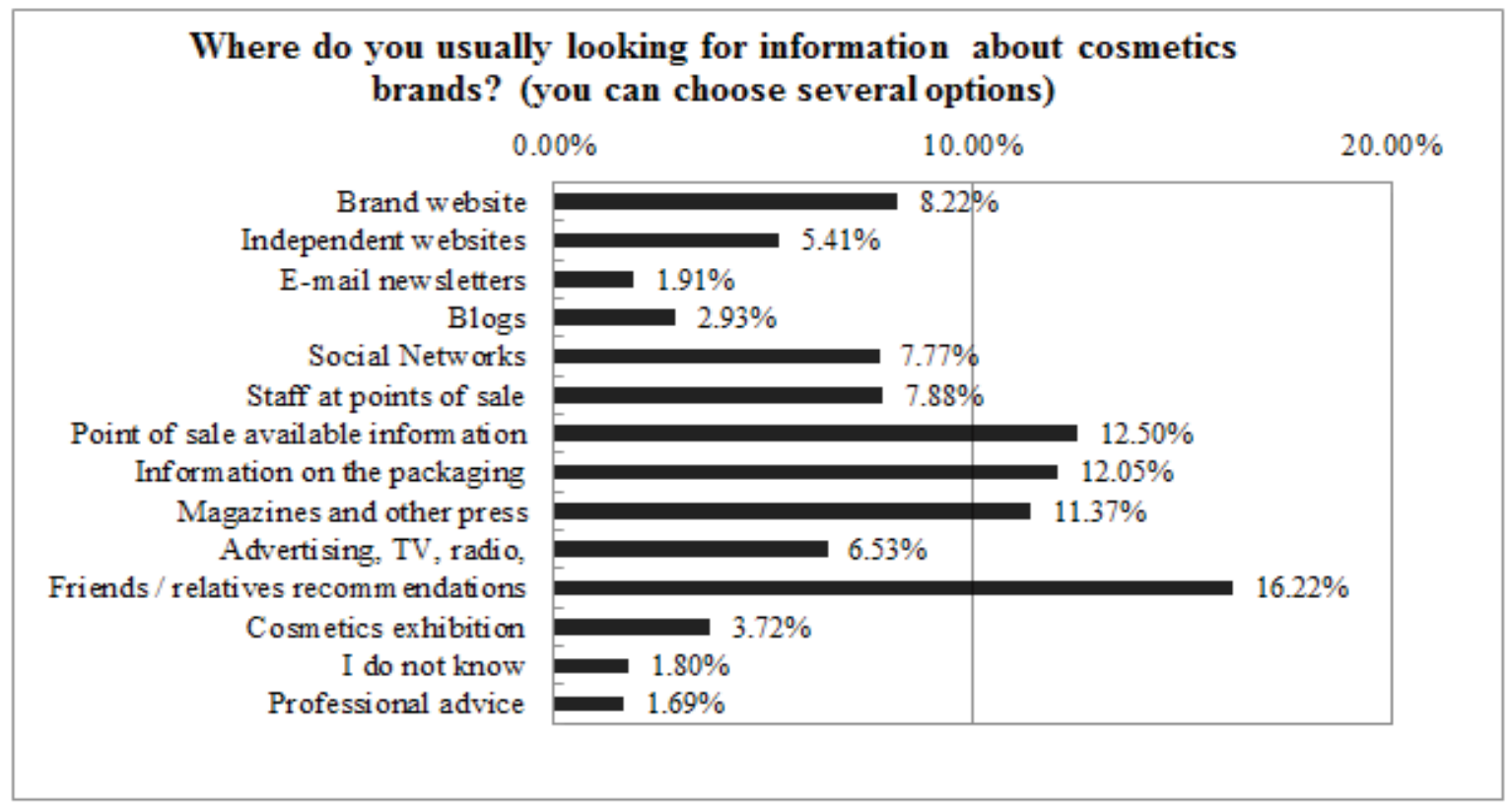

Figure 5. Cosmetic brands choice, $n=385$

Source: Results of author's performed survey

By assessing results, authors conclude that the most important external information source from consumers point of view is non-commercial personal verbal suggestion (WoM) made by consumer's relatives, colleagues or friends. Authors conclude that in market is being formed very favorable environment consumer roles increment in marketing communication and ability to impact brand and its reputation. Due to digital technologies' development the consumer created brand communication opportunities have been rapidly evolved, and previously dominated brand monologue with consumer has been transformed in interactive two-way communication. When choosing cosmetics, consumers also take other consumers thoughts into consideration, before they actually choses and purchases a product. Word-of-mouth takes more and more important role in marketing communication. As the research chows the most important information source that is being used by $16.22 \%$ of respondents is word-of-mouth. Interesting that for cosmetic consumers still the important source is magazines and other written press. This channel even overtakes social networks. Authors explain this with cosmetic brand consumer's high occurrence of emotional value, because magazines are emotional and satisfy consumer need for positive emotions.

Respondents were given an opportunity to express their thoughts about brand and consumer interrelationships, because with the critics starts progress. Approximately $60 \%$ of respondents thinks that brands are using them for selfish purposes and in reality brands doesn't have true interest about consumers and their needs. Only $28 \%$ of respondents believe that brands are honest with them and take care of them.

For choosing the brand and suggest it to others, approximately $50 \%$ of respondents believes that brands should honestly and openly communicate about product ingredients and origins. 


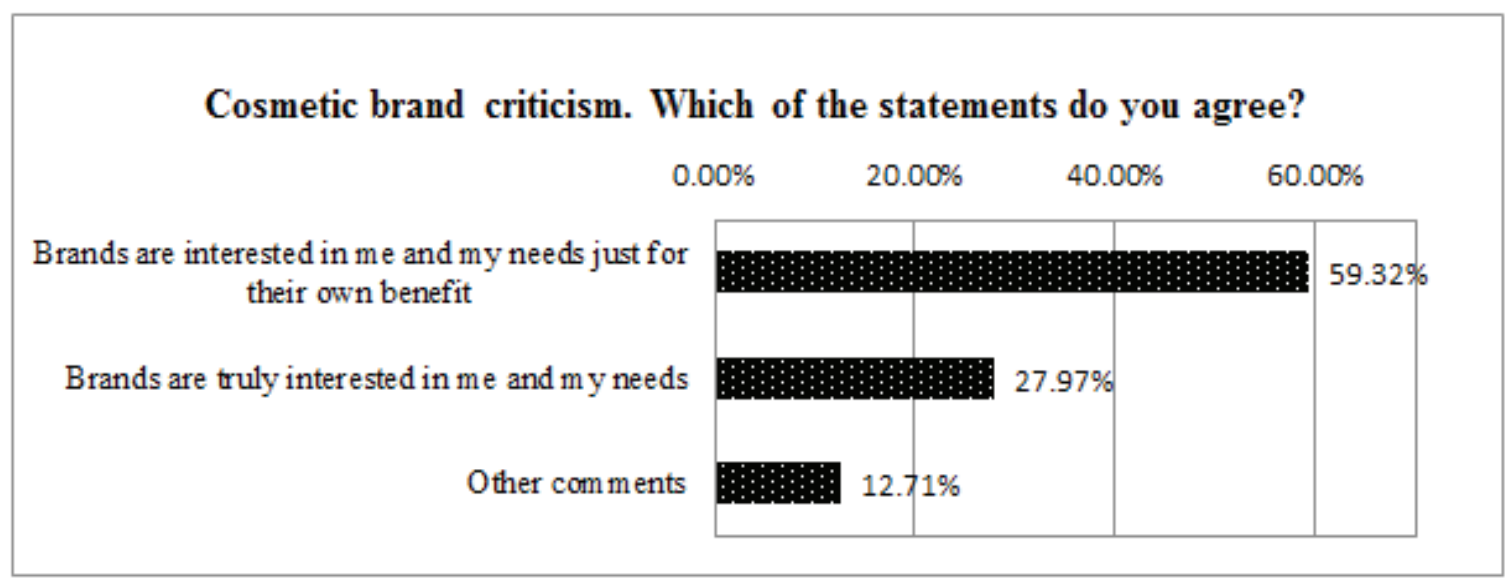

Figure 6. Cosmetics brand criticism, $n=385$

Source: Results of author's performed survey

Authors based on interviews with marketing and brand managers, and online available material analysis, analyzed cosmetics brand consumer value in 3 different price categories - low, medium and high price categories.

Authors conducted analysis after following model:

1. Brand awareness.

2. Brand associations.

3. Brand perceived quality, price and other values. Here consumer assessment is compared with brand manager's provided information in 10 point scale. Inter-assessment conditions:

- if assessment matches - highly successful brand equity communication;

- if assessment varies within $+/-1$ point - successful equity communication;

- if assessment varies within $+/-2$ points - average communication, but increased attention should be paid, and actions should be planned for improvements ( 2 points is average standard deviation in this research);

- if assessment varies within $+/-3$ or more points - communication is not successful, and it is necessary to make actions in order to significantly improve it.

4. Loyalty and trust to brand.

5. Consumers perceived communication; tools and channels.

When analyzing cosmetic brands authors conclude that low-priced cosmetic brands are widely represented in Latvian market, and this segment is highly competitive. Main players in this segment are global foreign brands with great experience. In this category brands are characterized by aggressive communication - advertisement in TV and environment, as well as advertisement or advertisement-articles in women weekly or monthly magazines with the goal to remind about themselves and create brand awareness that is vital in this category. It is important for these brands to embrace as many consumers as possible. Communication is usually standardized and templated, usually in product level. As consumers admit, the communication is not truly appropriate to Latvian consumer features - character, perception and habits. International brands have much product information in foreign web-pages and social media. In most cases this information is in English language, because most of brands are not willing to invest in relatively small Latvian market. In this cosmetics category main client attraction happens with product promotion: buy one and get second for free; discounts $-60 \%$ etc. Authors performed research shows that main criteria is benefits, quality-price ratio, simplicity of product, its simple usage and brand awareness. The loyalty in this market segment is low. 
Medium price cosmetic brands in Latvia are widely represented specifically with domestic producers. In this price category brands mostly choses lifestyle category by offering particular lifestyle perception and attracting concrete consumer segments. These brands are positioned as qualitative brands with natural ingredients that give consumer satisfaction. Both experts and consumers admit that Latvian brands somewhat copy big, respected foreigners. Authors believe that power of these brands hides in individual, unusual and creative communication with consumer. Still it is classic communication in product level. Here, main criteria are quality, natural components, awareness, Latvian brand and appropriateness to consumer lifestyle.

High price category cosmetic brands gives consumer higher feeling of safety, because with its quality they are offering high value. In this category consumers main criteria of choice are quality, modern design packaging, purchase emotional adventure and special individual attitude. Purchase of premium cosmetic for consumer is special adventure that satisfies their desires to special wellness and self-affirmation, as well as acknowledges consumers belonging to wealthy social group. In Premium-class cosmetic user segment consumers are more loyal to brands in comparison with mass cosmetic clients. Mostly this segment consists of consumers with high income, but here dream-fulfillers can also be met. Those are consumers with low or medium income, and they have planned this purchase and money resources for a longer period of time - in order to purchase their dream-cosmetics. Authors conclude that in this category the individual communication should be built for brands - communication that would emphasize this special status of product. In premium category it is important to appropriately train sales personnel, and create confidence about brand's value in them. Also professional brand consultant's suggestions are important. It is essential that brand representatives (sales people and consultants) are able to deliver the premium aura to consumers. It is most important within the purchase decision making process.

\section{Consumer based brand equity formation model in Latvian cosmetics market}

By performing wide literature theoretical analysis, studying scientific papers in various scientific databases and performing consumer value research, authors have acquired valuable insights and concludes that brand value creation is affected by multiple factors and processes, that authors summarizes in brand equity management model. The model consists of 4 main parts:

- Brand desired consumer value creation.

- Value communication.

- Consumer knowledge.

- Value affirmation in consumer's perceptions.

Model is simple and it clearly identifies brands and consumer's interaction, supports to navigate in complicated brand equity creation and maintenance process, and gives an opportunity to easily notice interconnections of actions.

Model is based on K. L. Keller and D. Aaker value models (revised in theoretical part), which authors interpret in their own analytical way, by using results of performed research. Model illustrates brand consumer value development process. Since consumer attitude and market are changing, also consumer value management is continuous process. By creating model authors' goal was to create logical, structured and easy-to-use marketing tool. 


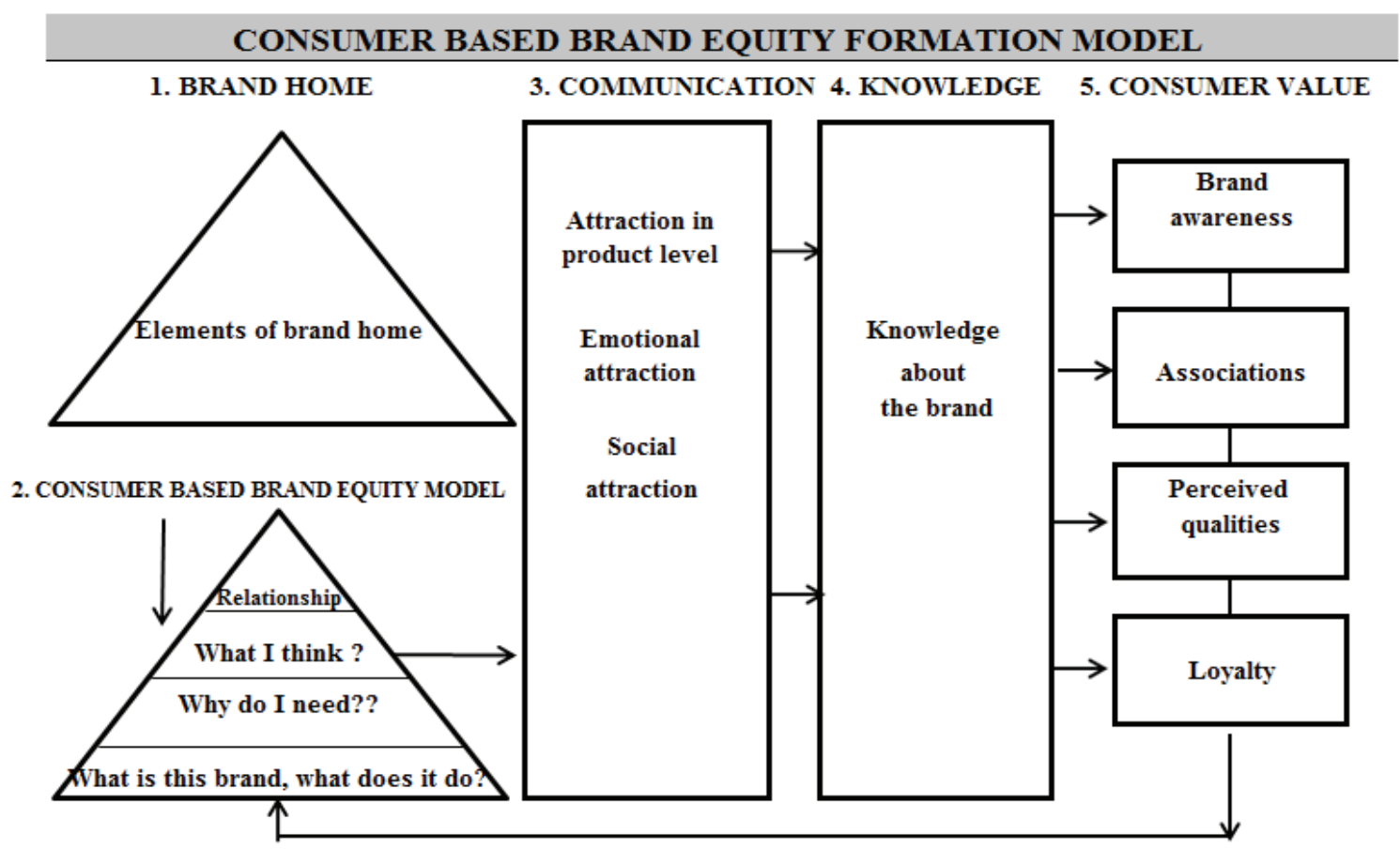

Figure 7. Consumer based brand equity formation model

Source: Created by authors

Brand home is essential part of brand creation that describes brand's main elements. The aim of this paper is not to research brand creation process therefore this is not detailed analyzed in the paper. It is part of the model because, guided by brand home elements, the brand consumer value pyramid is formed, so it is important in order to gain full overview. Consumer based brand value pyramid consists of 4 steps: brand identity creation, brand meaning creation, positive attitude formation and consumer's attraction to brand, and it consists of 6 basic elements. When creating brand value for consumers it is important to reach the top of pyramid. It can be reached only if below-standing elements are properly created. It is important to understand that every below-standing element affects top one. Below-standing elements or basics of pyramid are essentially important because they are forming comprehension about brand and brand attractiveness. These attributes are cornerstone when in their minds consumers are forming set of alternative brand choices. The more higher in the pyramid consumer gets, the stronger his attraction to brand is formed. By developing marketing activities, the goal should be values that are located in pyramids top. Still the brand managers should remember that these values have to be in the basics of all marketing activities, because it significantly determines consumer's feedback and response. If it will not be consequently obeyed, consumer simply could not develop strong notion about brand. Brand communication, is main, but not only, brand consumer value creation tool. In this step the main goal is to attract and maintain consumer as well as effectively deliver desired information with communication message. Here it is important to communicate not only in product level, but also in emotional and in such problem level that is important for society. In Latvian market actualizes the need to use communication channels and tools that are relevant to digital age. Those channels and tools should be combined with existing traditional marketing communication, consumer knowledge about brand. It directly affects consumer's value creation and purchase decision making process and results. Knowledge is broad term, but in brand context it is formed and resulted in perception of brand awareness, associations, values, quality and other attributes, as well as in consumer loyalty. All these components forms model's consumer based brand equity. Consumers can acquire knowledge from different sources. It is only important 
that all the knowledge would originally arose from brand itself or at least from brands reliable consumer, and formed desired brands composition in consumer's minds.

Brand equity in consumer's minds cannot be directly measured. But it can be explored by using various research methods. With the help of quantitative or qualitative consumer surveys the valuable and useful data can be acquired which then are analyzed after consumer value perception components that are listed in $5^{\text {th }}$ block. Authors believe that in researches all of these components have to be included, and data have to be analyzed both united and separately for each component, because this kind of analysis develops full picture of consumer value and more precisely allows evaluating consumer attitude and necessary actions. Value creation, management and research require situations full comprehension and great workload from brand managers. Most importantly is to understand that brand's true power lies into consumers. By analyzing components of consumer's value, it is possible to analytically understand and explore causes and consequences, and opposite. That is the main principle of authors provided model.

\section{Conclusions}

Cosmetic brands occupy significant role in Latvian consumer's lives. Research approves that consumers who do not have their favored brand chose products among brands that they already know. Cosmetic brands in Latvia are very little researching their consumers, no one from the analyzed brands has performed consumer value research. Analyzing this brand consumer value, the gaps are revealed in consumer brand perception which brands have not identified. The main brand based consumer value determining criteria in Latvian cosmetics market is quality. $69 \%$ from respondents gave quality the highest assessment (10 points). Latvian consumers are becoming more educated and pay more attention to products ingredients and quality - they are evaluating how good the product will be in the long run.

Due to increment in consumers income within the last few years Latvian consumers chose to acquire more expensive products. Even though the price is still taken into account (and it is $2^{\text {nd }}$ most important criteria when choosing the brand), not always lower price turns out to be automatically choice. Research data shows that people are buying products with the higher quality. Consumer research proves that the brands emotional attraction in consumers consciousness are increasing brand's value, functional need have to be linked with consumer's emotional values, it is clearly visible in brands example. Next to rational and emotional values, social values are loudly announcing themselves in consumer's minds. Latvian consumer's cares that brands are created around better, socially more responsible environment and their performed actions would be harmless to the environment. Therefore cosmetic brands in Latvian market should be necessary positioning which would be based also on social society's values, because brand's social responsibility are becoming increasingly important for consumer.

Brands communication in general lacks uniqueness. According to cosmetic experts, consumers and even global brands managers, brand advertisement in Latvia generally is standardized and doesn't match with the Latvian consumer's perception. Brands need interactive communication. Most of cosmetic brands in Latvian market are still using predominantly classic forms of marketing communication. The most important external information source, in which consumer listens to, is non-commercial personal advice received from relative, friend or colleague. Word-of-mouth takes increasingly important role in marketing communication. In order to choose brand or suggest it to others, Latvian cosmetic consumers believes that brands should honestly and openly communicate about product's ingredients and origins. Brands needs to have more honest attitude towards consumers. $60 \%$ of consumers believe that brands are just using them for selfish purposes and in reality brands are not attracted to true interest about consumer and their needs. Brand consumer value main insight is that brand's power lies in consumers knowledge about brand, and knowledge together with experience creates brand's image, associations and value in consumers perception. Consumer based brand equity is significant cornerstone for brand's success in economic terms. It is necessary to continue further research - conduct qualitative in-depth interviews with marketing representatives in more companies in order to gain more comprehensive insight into brand equity management und formation issues and problems in Latvia. 


\title{
References
}

Aaker, D. A. (2014). Aaker on branding. Morgan James Publiching: New York.

Aaker, D. A. (1991). Managing Brand Equity. Capitalizing on the Value of Brand Name. The Free Press: New York, NY. Aaker, D. A. (2009). Managing Brand Equity. Simon and Schuster.

Abdel Fattah Al-Azzam. (2013). Analysis of the antecedents of customer-based brand equity. Interdisciplinary Journal of Contemporary Research in Business, Vol. 5, No. 5, p. 73-74.

American Marketing Association Dictionary. (2009). Available online at http://www.marketingpower.com/layouts/Dictionary.aspx [accessed on 10.05.15].

Batraga, A., Medne, I., Dmitrijeva, K., Šalkovska, J. (2013). Development of higher education institution brand - association context. Academic Journal EBSCO, Economic Science for Rural Development Conference Proceedings, No. 32, p. 141.

Buil, I., Martínez, E., De Chernatony, L. (2013). The influence of brand equity on consumer responses. Journal of Consumer Marketing, Vol. 30, No. 1, p. 62-74.

Fayrene, C. Y. L, Goi Chai Lee. (2011). Customer-based brand equity: a literature revie. International Refereed Research Journal, Vol. 2, No.1, p. 34-35.

Gunelius, S. (2014). Brand Equity Basics. Part 1: What Is Brand Equity? AYTM blogs, available online at https://aytm. $\mathrm{com} / \mathrm{blog} /$ research-junction/brand-equity-basics-1/ [accessed on 11.05.15].

Kamakura, A. W., Russell, G. J. (1993). Measuring brand value with scanner data. International Journal of Research in Marketing, Vol. 10, No. 1, p. 9-22.

Kapferer, J. N. (2008). New strategic brand management: creating and sustaining brand equity long term. 4th ed. Kogan Page.

Kardes, F. R., Cronley, M., Cline, T. (2010). Consumer behavior: science and practice. South-Western.

Keller, K. L. (1993). Conceptualizing, Measuring, and Managing Customer-Based Brand Equity. Journal of Marketing, Vol. 57, No. 1, p. 1-22.

Keller, K. L. (2013). Strategic Brand Management: Building, Measuring, and Managing Brand Equity. 4th edition. Pearson Education Limited, England.

Kenyon, G. N., Sen, K. C. (2015). The perception of Quality. Springer London.

Kotler, P., Keller, K. L. (2006). Marketing Management. Pearson Education, Upper Saddle River.

Lindemann, J. (2010). The Economy of Brands. Palgrave Macmillan.

McCort, D. J., Malhorta, N. K. (1993). Culture and Consumer Behavior. Journal of International Consumer Marketing, Vol. 6, No. 2, p. 91-127.

Monday. (2010). E-Journal, available online at http:/www.monday.lv/par-latvisko-zimolu-stastu/ [accessed on 30.04.2015].

Pullig, C. (2008). Keller Center Research Report. Baylor University.

Shimp, T. A. (2010). Integrated Marketing Communication in Advertising and Promotion. South Melbourne Tybout, A. M., Calder, B. J. (2010). Kellog on Marketing. 2nd ed. Wiley \& Sons. Chapter 6.

\section{LATVIJOS VARTOTOJUQ SUVOKIAMA KOSMETIKOS PREKÉS ŽENKLOVERT}

\author{
Jelena Šalkovska, Anda Batraga, Aelita Mežpapa \\ Latvijos universitetas (Latvija)
}

\section{Santrauka}

Sukurti stiprų prekès ženklą ir prekès ženklo vertę yra vienas iš verslo organizacijos tikslų. Prekės ženklo kūrimas priklauso nuo finansinių galimybių ir vartotojų prekės ženklo suvokimo. Tai aktuali verslo problema. Straipsnyje analizuojama įvairių prekės ženklų prisotinta Latvijos kosmetikos rinka, kur jaučiama ypač didelè konkurencija. Kosmetikos rinkoje aktyviai bendraujama su vartotojais. Kosmetikos rinka kuria savo unikalius prekės ženklus ir stengiasi įtikinti vartotojus rinktis jų produktus. 
Tyrimo tikslas suformuluotas remiantis teorinėmis nuostatomis apie prekès ženklo vertès kūrimą, atlikus kokybinị ir kiekybinị tyrimus 2015 metų sausio - gegužès mėnesiais. Imti interviu iš Latvijos rinkodaros specialistų, kosmetikos prekès ženklų ekspertų. Naudotasi ir statistiniais duomenimis, siekiant palyginti gautus tyrimo rezultatus.

Tyrimo rezultatai atskleidè, kaip Latvijos vartotojai vertina kosmetikos prekių ženklus, jų kokybę. Kaina yra vienas iš prekès vertę nurodančių veiksnių, nors tai ne pagrindinis vertinimo kriterijus. Šalia racionalios ir emocinès vertès yra socialinė vertė, glūdinti vartotojų sąmonejje. Latvijos kosmetikos vartotojai labiau vertina tuos prekès ženklus, kurie yra socialiai atsakingi, jų veikla mažiau kenkia aplinkai. Taigi Latvijos vartotojai vis labiau renkasi tuos prekès ženklus, kurie yra atsakingesni.

Prekès vertès kūrimo, valdymo ir tyrimų šioje kryptyje atlikimas yra svarbi ir būtina vadovų darbo dalis. Apibendrinę tyrimo rezultatus, autoriai siūlo vartotojų suvokiamos kosmetikos prekės ženklo vertès modelį. Modelis yra paprastas ir aiškiai atskleidžia prekès ženklo bei vartotojų tarpusavio sąveiką, padeda sukurti prekès ženklo vertę, atlikti būtinas korekcijas.

PAGRINDINIAI ŽODŽIAI: vartotoju suvokiama prekès ženklo vertè, kosmetikos prekès, suvokiama kokybe.

JEL KLASIFIKACIJA: M31 